\title{
Drought-adapted maize line based on morphophysiological selection index
}

\author{
RUSNADI PADJUNG ${ }^{1, \vartheta}$, MUH FARID ${ }^{1, v v}$, YUNUS MUSA $^{1}$, MUHAMMAD FUAD ANSHORI ${ }^{1}$, AMIN NUR $^{2}$, \\ ANDI MASNENONG ${ }^{3}$ \\ ${ }^{1}$ Department of Agronomy, Faculty of Agriculture, Universitas Hasanuddin. Jl. Perintis Kemerdekaan Km 10, Makassar 90245, South Sulawesi, \\ Indonesia. Tel.+6281355041712, ^email: rusnadi2015@gmail.com, vvemail: farid_deni@yahoo.co.id \\ ${ }^{2}$ Assessment Institute for Agriculture Technology of Gorontalo. J1. Mohamad Van Gobel No. 270, Iloheluma, Bone Bolango 96583 , Gorontalo, Indonesia \\ ${ }^{3}$ Program of Agrotechnology, Faculty of Agricultural, Universitas Hasanuddin. Jl. Perintis Kemerdekaan Km 10, Makassar 90245, South Sulawesi, \\ Indonesia
}

Manuscript received: 21 May 2021. Revision accepted: 29 August 2021.

\begin{abstract}
Padjung R, Farid M, Musa Y, Anshori MF, Nur A, Masnenong A. 2021. Drought-adapted maize line based on morphophysiological selection index. Biodiversitas 22: 4028-4035. Synthetic line formation is an effort to increase maize productivity in drought-stressed areas. This process requires systematic selection in determining adaptability levels involving important secondary characters formulated in the selection index. Furthermore, the principal component index had been widely reported, both in normal and stressed conditions. The selection index development on morpho-physiological characters based on multivariate analysis was expected to increase drought stress tolerance and maize lines selection precision. Therefore, the purpose of this research was to form a selection index based on morpho-physiological characters and selecting synthetic lines adaptive under drought stress. This research was designed using a split-plot with 3 replications, where the main plot consisted of normal and stressed irrigation, while the subplot was genotype consisting of 6 lines and 3 check varieties namely Bisma, Lamuru, and Sukamarga. Observations were performed on 18 morphological and 4 physiological characters, and the results showed that the selection index was formed based on multivariate analysis from 9 characters. Through index selection, Syn_2-2 (0.79), Syn_2-15 (0.85) and Syn_2-16 (0.97) were considered as drought stress adaptive lines. Therefore, the 3 lines can be recommended in the synthetic variety release process.
\end{abstract}

Keywords: abiotic stress, corn, multivariate analysis, principal component, secondary characters

Abbreviations: 1000SW: 1000 Seed Weight; ASI: Anthesis Silking Interval; DAP: Day After Planting; DFF: Days of Female Flowering; DMF: Days of Male Flowering; ED: Ear Diameter; EH: Ear Height; EL: Ear Length; LR: Leaf Rolling; NDL: Number of Dried Leaves; NL: Number of Leaves; PH: Plant Height; Pr: Productivity

\section{INTRODUCTION}

Maize (Zea mays L.) is an important feed and food in Indonesia. This commodity also is one of the main ingredients of industrial companies, which makes it the 3rd important cereal commodity in the world after wheat and rice (Bukhsh et al. 2012; Cooper et al. 2014). In Indonesia, maize production is considered good, reaching 30 million tons in 2018 (Agriculture Ministry 2018). However, as population growth increases, annual maize production also needs to further increase to meet the demand (Sah et al 2020; Badr et al. 2020). Climate change negatively impacts the plant growth environment, such as drought, salinity, submergence, etc. (Raza et al. 2018). The prolonged temperature rise due to climate change induces drought stress, which in turn threatens the maize production stability (Fahad et al. 2017), and as a result, domestic production has failed to meet the demand. Therefore, the maize production problem in drought stress conditions should be solved to increase the maize yield.

Generally, water scarcity caused by limited water availability on agricultural land or plant inability to absorb water is a common drought stress factor (Farid et al. 2019).
This stress can inhibit some plant morphology and physiological processes, such as cell division, cell development, nutrient transport and translocation, plant enzymatic process, plant metabolism, pollen sterility, and grain development, which affect the growth and yield of plants, including the maize (Silva et al. 2013; Fahad et al. 2017). Although maize is known to use water efficiently (Ghannoum 2009), a long period of drought stress, both at vegetative stage and at the anthesis stage, will decrease production (Witt et al. 2012; Souza et al. 2013; Song et al. 2019; Sah et al. 2020). According to Monneveux et al. (2005) and Sah et al. (2020), drought stress can decrease maize yield by $17-60 \%$ in tropical areas. Song et al. (2019) also reported that the drought stress could decrease the maize yield up to $50 \%$ from 2013 to 2016 . Therefore, this problem needs to be solved through, among others, developement of drought stress adapted maize variety.

Maize variety can be developed through hybridization and open-pollination. The hybrid is a popular variety in maize (Fromme et al. 2019; Kandel 2020) because it is relatively sensitive under stress conditions (Kutka 2011; Sharma et al. 2019). However, the synthetic variety is more adaptive under stress conditions, making it suitable for 
development (Kutka 2011; Freshley and Delgado-Serrano 2020). The adaptive variety produces good yield and growth characters in any environment, including stress conditions (Lin et al. 1986; Fadhli et al. 2020). To produce the variety possessing this trait, the combination of the yield supporting characters, known as secondary characters, must be studied. The yield is mostly comprised of polygenic traits Hence, secondary supporting characters can keep potential lines in any environment (Kassahun et al. 2013; Fellahi et al. 2018), especially under drought stress conditions. Sabouri et al. (2008), Saad et al. (2014), Fellahi et al. (2018), and Anshori et al. (2019) have reported the assessment of tolerance lines involving the secondary characters. Besides, according to Fadhli et al. (2020), using the secondary character in selecting adapted lines under drought stress was more effective. Therefore, these characters are important in selecting the adapted synthetic maize under drought stress.

Secondary characters can be obtained through morphology and physiology characterization. These combinations present strength that can be considered in a selection for adapted lines under stress conditions. Previous reports on this concept under drought stress have been made by Barik et al. (2019) on rice, Souza et al. (2013), and Sabagh et al. (2017) on maize. However, combining all secondary characters and yield requires a selection formula known as the selection index. This is the linear multivariate regression consisting of specific weighted criteria selection (Rajamani et al. 2016; Islam et al. 2017). Moreover, the index needs systematic analyses such as multivariate analysis to determine the fit of secondary characters and the weighting of its secondary characters. The success of this approach has been reported by Sabouri et al. (2008), Peternelli et al. (2017), Kose et al. (2018), Branković et al. (2018), Akbar et al. (2019), and Anshori et al. (2021). Therefore, applying multivariate analysis to develop a selection index based on morpho-physiological characters is useful in adaptive synthetic maize under drought stress. The objective of this study was to develop a selection index based on morpho-physiological characters and select the adapted synthetic maize lines under drought stress.

\section{MATERIALS AND METHODS}

The study was conducted in the Experimental Farm of Faculty of Agriculture, Hasanuddin University, Makassar from July to November 2017. This research was designed using a split-plot design with 3 replications where main plot watering (p) consisted of normal (p0) and stress irrigation (p1). Also, Subplots consisted of 6 genotypes (G): Syn 2-1 (G1), Syn 2-2 (G2), Syn 2-4 (G3), Syn 2-8 (G4), Syn 2-15 (G5), Syn 2-16 (G6) and 3 check varieties, i.e., bisma (G7), lamuru (G8) and sukmaraga (G9). According to the number of treatments, 18 combination was present and replicated 3 times, resulting in 54 experimental units while the plotting area for experimental unit size was $3 \mathrm{bm} \times 3.5 \mathrm{bm}$.

\section{Experimental procedure}

To prevent mildew disease, maize seeds used were given metalaxyl. Seeds (2) were placed in each planting hole and Carbofuran $30 \%$ was added with $15 \mathrm{~kg} \mathrm{ha}^{-1}$ dosage to prevent pest infestation. Furthermore, each genotype treatment was planted in a $80 \mathrm{~cm} \mathrm{x} 20 \mathrm{~cm}$ spacing, the thinning was done 14 days after planting (DAP), and fertilizer was applied 3 times. First fertilizer application (basal application) was applied seven days after planting at dosage of SP36 $150 \mathrm{~kg} \mathrm{ha}^{-1}, \mathrm{KCl} 100 \mathrm{~kg} \mathrm{ha}^{-1}$, and Urea $70 \mathrm{~kg} \mathrm{ha}^{-1}$. The second fertilizer application was on 28 DAP with NPK $100 \mathrm{~kg} \mathrm{ha}^{-1}$ and Urea $65 \mathrm{~kg} \mathrm{ha}^{-1}$, while, the third application was on $40 \mathrm{DAP}$ with $\mathrm{KCl} 100$ $\mathrm{kg} \mathrm{ha}^{-1}$ and Urea $65 \mathrm{~kg} \mathrm{ha}^{-1}$. Also, irrigation was made with a water pump hosed by flooding the plots until it got to the height of the beds. Drought stress method was performed according to CIMMYT (Bänziger et al. 2000), where irrigation was stopped after the plants attained 40 DAP. Afterward, irrigation was avoided for the next 30 days and was given on the 70th day until physiological maturity. As for the normal condition, the irrigation was done by using the pump for the regular watering of fields. Plant maintenance included thinning, heaping, spraying, and weeding. Weeding was performed on 14 and 28 DAP and Insecticide application was adjusted according to the crop pests present in the experimental field.

\section{Observation}

Observations were done morphological and agronomical characters consisted of plant height, number of leaves, leaf angle, leaf width, number of dried leaves, days to female flowering, days to male flowering, Anthesis Silking Interval (ASI), days to harvesting, stem diameter, ear length, ear diameter, length of seeded ear, seed rendement, 1000 seed weight, and productivity. Meanwhile, the physiological character's observations were done on leaf age scoring, absorption level, reflection, stomata density, leaf chlorophyll index, and leaf roll scoring. The tools used for physiology character observations were lab miniature leaf streptic CI 7010 and chlorophyll meter SPAD 502.

\section{Data analysis}

Recapitulated data were subjected to analysis of variance and characters significantly affected were preceded into further analysis. Variance identification was performed using cluster analysis under normal and drought-stressed conditions. This was done in Rstudio 3.6.3 with factoextra (Kassambra and Mundt 2020) and dendextend (Galili 2015). Additionally, all characters showing significant interaction effect were subjected to analysis of stress tolerance index (STI) (Fernandez 1992), as follow:

$$
\mathrm{STI}=\frac{Y p \times Y s}{\bar{Y} p^{2}}
$$

Where:

Yp : The character value of each line in normal conditions

Ys : The character value of each line in drought stress condition 
$\bar{Y} \mathrm{p}$ : Average character values of all lines in normal conditions

After which they were analyzed by using a Pearson correlation analysis. This analysis was performed using Rstudio software with Agricolae package (Mendiburu 2020) and corrplot (Wei and Simko 2017) while, the selection index was formed through principal component analysis using STAR IRRI 2.0.1 (Anshori et al. 2019). Furthermore, the selection index applied to all genotypes was evaluated by comparing the synthetic maize lines index with the best comparing index.

\section{RESULTS AND DISCUSSION}

Analysis of variance indicated that morphological and physiological characters were significantly affected by genotypic variance and water condition (Table 1). However, not all characters were affected significantly by interaction variance. Morphological characters that were affected included plant height, number of leaves, number of dried leaves, days to female flowering, days to male flowering, Anthesis Silking Interval (ASI), ear height, ear diameter, ear length, leaf rolling, 1000 seed weight and productivity. Meanwhile, the physiological characters affected were reflection and chlorophyll. According to AlNaggar et al. (2015), Mohamadi et al. (2017), Anshori et al. (2019) and Anshori et al. (2021), characters are significantly affected by genotype-environment interaction can exhibit response variance between genotype and growing environment factors. This is a base in distinguishing adapted or tolerant and sensitive maize genotypes under drought stress. A similar concept application was reported by Fadhli et al. (2020) on maize under drought stress, Anshori et al. (2021) on rice under salinity stress, and Akbar et al. (2019) on rice under drought stress. Therefore, all characters significantly affected by the interaction of genotype - water condition variance could be continued in further analysis.

Cluster analysis was the second approach to detecting interaction variance lines under normal and stress conditions. The results showed that synthetic maize genotype grouping experienced dynamic changes in both environments (Figure 1), and there was no straight line connecting the two dendrograms. Although on the $60 \%$ dissimilarity degree, both dendrograms had 3 cluster units with different group units in each. This shows that each genotype had a different response in every environment. Based on the result, cluster analysis was effective in depicting response variance in different growing environments. Some research has reported this by identifying relationships among objects towards many variables in several environments or models (Silva et al. 2013; Saad et al. 2014; Anshori et al. 2020). However, the simple dendrogram could not explain the specifically adapted trait under stress conditions. This proves that further analysis was required to evaluate the adaptability of synthetic maize under drought stress.

Table 1. Analysis of variance of morphological and physiological characters of a number of synthetic maize genotypes in varied environments

\begin{tabular}{|c|c|c|c|c|c|c|c|}
\hline Characters & Irrigation (E) & Error a & Genotype (G) & $\mathbf{G} \times \mathbf{E}$ & Error b & CVa & $\mathbf{C V b}$ \\
\hline Plant height & $5998.52^{* *}$ & 44.34 & $698.23^{\text {*** }}$ & $193.06^{*}$ & 79.04 & $4 \%$ & $5 \%$ \\
\hline Number of leaves & $14.00^{* *}$ & 0.02 & $1.45^{* *}$ & $0.58^{* *}$ & 0.15 & $1 \%$ & $4 \%$ \\
\hline Number of dried leaves & $27.45^{* *}$ & 0.07 & $0.49^{* *}$ & $0.20^{* * *}$ & 0.06 & $13 \%$ & $12 \%$ \\
\hline Stem diameter & $41.93^{*}$ & $\begin{array}{l}0.01 \\
1.59\end{array}$ & $3.01^{*}$ & $0.52 \mathrm{~ns}$ & 1.11 & $6 \%$ & $5 \%$ \\
\hline Days to female flowering & $80.67^{*}$ & 0.89 & $4.00^{* *}$ & $3.37^{*}$ & 0.59 & $2 \%$ & $1 \%$ \\
\hline Days to male flowering & $20.17^{* *}$ & $\begin{array}{l}0.09 \\
1.06\end{array}$ & $4.21^{*}$ & $2.08^{* * *}$ & 0.77 & $2 \%$ & $2 \%$ \\
\hline Anthesis Silking Interval (ASI) & $20.17^{* *}$ & 0.17 & $1.27^{*}$ & $1.83^{* *}$ & 0.51 & $15 \%$ & $27 \%$ \\
\hline Days of harvest & $136.96^{*}$ & 5.57 & $15.88^{*}$ & $6.59 \mathrm{~ns}$ & 4.44 & $2 \%$ & $2 \%$ \\
\hline Ear height & $1717.84^{*}$ & 60.87 & $216.49^{\text {*** }}$ & $149.31^{*}$ & 59.55 & $8 \%$ & $8 \%$ \\
\hline Ear diameter & $80.87^{*}$ & 1.17 & $5.88^{* *}$ & $5.11^{* * *}$ & 1.13 & $5 \%$ & $5 \%$ \\
\hline Leaf angle & $553.30^{* *}$ & 5.42 & $22.40^{*}$ & $7.84 \mathrm{~ns}$ & 7.54 & $8 \%$ & $10 \%$ \\
\hline Leaf width & $90852.41^{*}$ & 2895.94 & $9762.18^{*}$ & $3877.43 \mathrm{~ns}$ & 4268.73 & $12 \%$ & $14 \%$ \\
\hline Leaf aging & $1.97^{* *}$ & 0.02 & $0.06^{* *}$ & $\begin{array}{l}0.04 \mathrm{~ns} \\
0\end{array}$ & $\begin{array}{c}4200.15 \\
0.02\end{array}$ & $3 \%$ & $\begin{array}{l}14 \% \\
5 \%\end{array}$ \\
\hline Absorption & $1.97^{*}$ & 0.02 & $0.06^{* *}$ & $0.04 \mathrm{~ns}$ & 0.02 & $18 \%$ & $16 \%$ \\
\hline Reflection & $0.06^{* *}$ & 0.00 & $0.00^{* *}$ & $0.00^{*}$ & 0.00 & $11 \%$ & $8 \%$ \\
\hline Stomata density & $4129.96^{* *}$ & 36.92 & $1346.99^{*}$ & $633.53 \mathrm{~ns}$ & 461.46 & $2 \%$ & $8 \%$ \\
\hline Leaf rolling & $22.56^{* *}$ & 0.00 & $0.05^{* *}$ & $0.02^{*}$ & 0.01 & $2 \%$ & $3 \%$ \\
\hline Leaf chlorophyll index & $1244.23^{*}$ & 56.25 & $297.95^{* *}$ & $166.79^{*}$ & 70.89 & $1 \%$ & $1 \%$ \\
\hline Ear length & $71.67^{*}$ & 0.94 & $4.45^{* *}$ & $2.02^{* *}$ & 0.35 & $6 \%$ & $4 \%$ \\
\hline Seed rendement & $365.50^{* *}$ & 1.52 & $6.70^{*}$ & $5.01 \mathrm{~ns}$ & 2.96 & $2 \%$ & $2 \%$ \\
\hline 1000 sed weight & $8151.69^{*}$ & 210.70 & $3634.07^{* *}$ & $403.89^{*}$ & 143.89 & $4 \%$ & $4 \%$ \\
\hline Productivity & $170.40^{* * *}$ & 0.18 & $3.73^{* *}$ & $0.40^{* *}$ & 0.08 & $6 \%$ & $4 \%$ \\
\hline
\end{tabular}

Note: $\mathrm{CV}$ : coefficient of variance; ${ }^{*}$ significant at $5 \% ;{ }^{* *}$ highly significant at $1 \%$ level; ns: not significant 


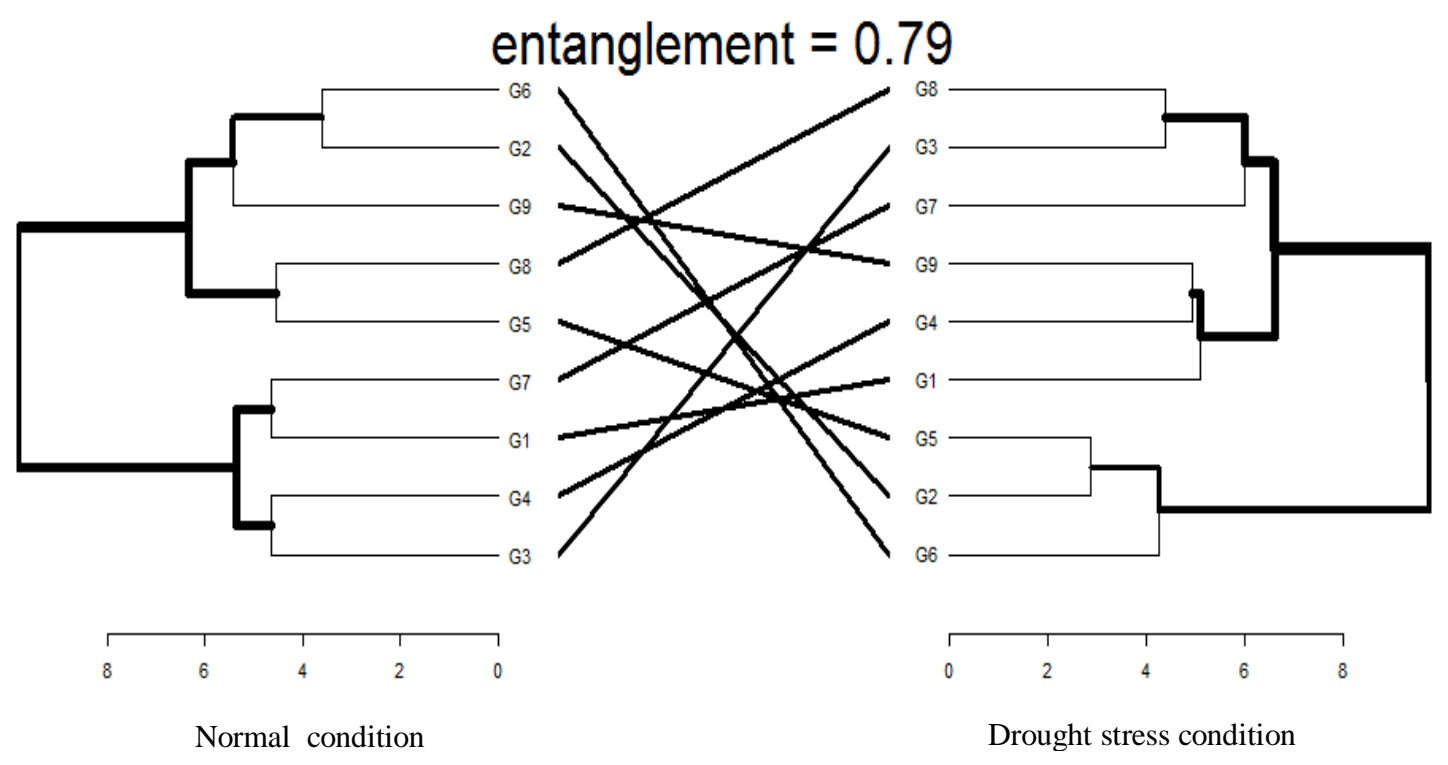

Figure 1. Cluster analysis of synthetic maize lines based on significant characters toward the interaction effect under normal and drought condition

The effectiveness of tolerance and adaptability can be evaluated with Stress Tolerance Index (STI). This detects tolerant lines under stress and has a midpoint benefit in considering the line's potential under normal and stress conditions (Anshori et al. 2019). Besides, STI considers the average responses of all genotypes under normal conditions. This is similar to a dynamic concept on the stability analysis used in assessing the stability lines (Hidayatullah et al. 2019; Kartina et al. 2019; Sitaresmi et al. 2019; Amzeri et al. 2020). Furthermore, the dynamic concept can assess the line's potential based on the average population responses (Lin et al. 1986), hence, the STI concept could be used in detecting adapted or tolerant lines. The application of the index to genotype tolerance and adaptability under environmental stress has been widely reported. Anshori et al. (2018) and Anshori et al. (2019) had previously applied this method in salinity-stressed rice, while, Kumar et al. (2015). A similar application has been made by Fadhli et al. (2020) on drought-stressed maize and Farid et al. (2019) on drought-stressed wheat. In addition, STI application on several characters had been reported by Anshori et al. (2019) and Fadhli et al. (2020). Therefore, STI application on characters significantly affected by the treatments was also used in this research.

Correlation analysis of STI values and the significantly affected characters showed that productivity was correlated positively to plant height (0.77), the number of leaves (0.76), ear height position (0.78), ear diameter (0.72), and 1000 seed weight (0.72). However, a negative sign was observed on the number of dried leaves (-0.84) (Figure 2). Some research has also reported these correlations, such as the correlation of ear diameter and number of leaves to productivity reported by Fadhli et al. (2020). Additionally, Ali et al. (2017) reported a significant positive correlation between productivity and ear diameter, while Yue et al. (2018) reported a significant correlation between yield and plant height. Leaf rolling has a negative correlation with the number of leaves $(-0.89)$, plant height $(-0.68)$, ear height (-0.68), and chlorophyll (-0.67) (Figure 2). This was due to its negative interpretation, where the more adapted the variety under drought, the less the leaf curling occurred (Efendi et al. 2019; Fadhli et al. 2020). Commonly, productivity is the main selection character, but various research was based on drought stress tolerance determination on leaf rolling (Obeng-Bio et al. 2011; Baret et al. 2018; Efendi et al. 2019). According to correlation analysis, an indirect correlation was discovered between leaf rolling and productivity in drought stress. This was proven in plant height, number of leaves, and ear height, significantly correlated with both characters. Furthermore, this indicated that the combination of these characters can increase drought selection accuracy. Therefore, the characters need to be combined in a selection index, and this can be analyzed through principal component analysis. Anshori et al. (2019), Akbar et al. (2019), Alsabah et al. (2019), and Anshori et al. (2021) had reported the index formation in this analysis.

Principal Component Analysis (PCA) result showed that 3 PC depicted STI characters (Table 2). This determination was based on the early PC that attained 0.8 cumulative variances (CV) (Jolliffe 2002). Based on CV value, PC1 to PC3 were determined as the potential candidates on the weighting index. Furthermore, the PC1 was the most productive eigenvector compared to PC 2 and PC 3, making this PC the basis for the weighing index (Table 2). A similar trend was previously reported by Anshori et al. (2019), Akbar et al. (2019), and Anshori et al. (2021), where the formation of selection index weighting value was based on the largest eigenvector from the main characters. Despite this, PC1 had a negative value, but its eigenvector was still used as a base of the weighing index, as was applied by Anshori et al. (2021). 


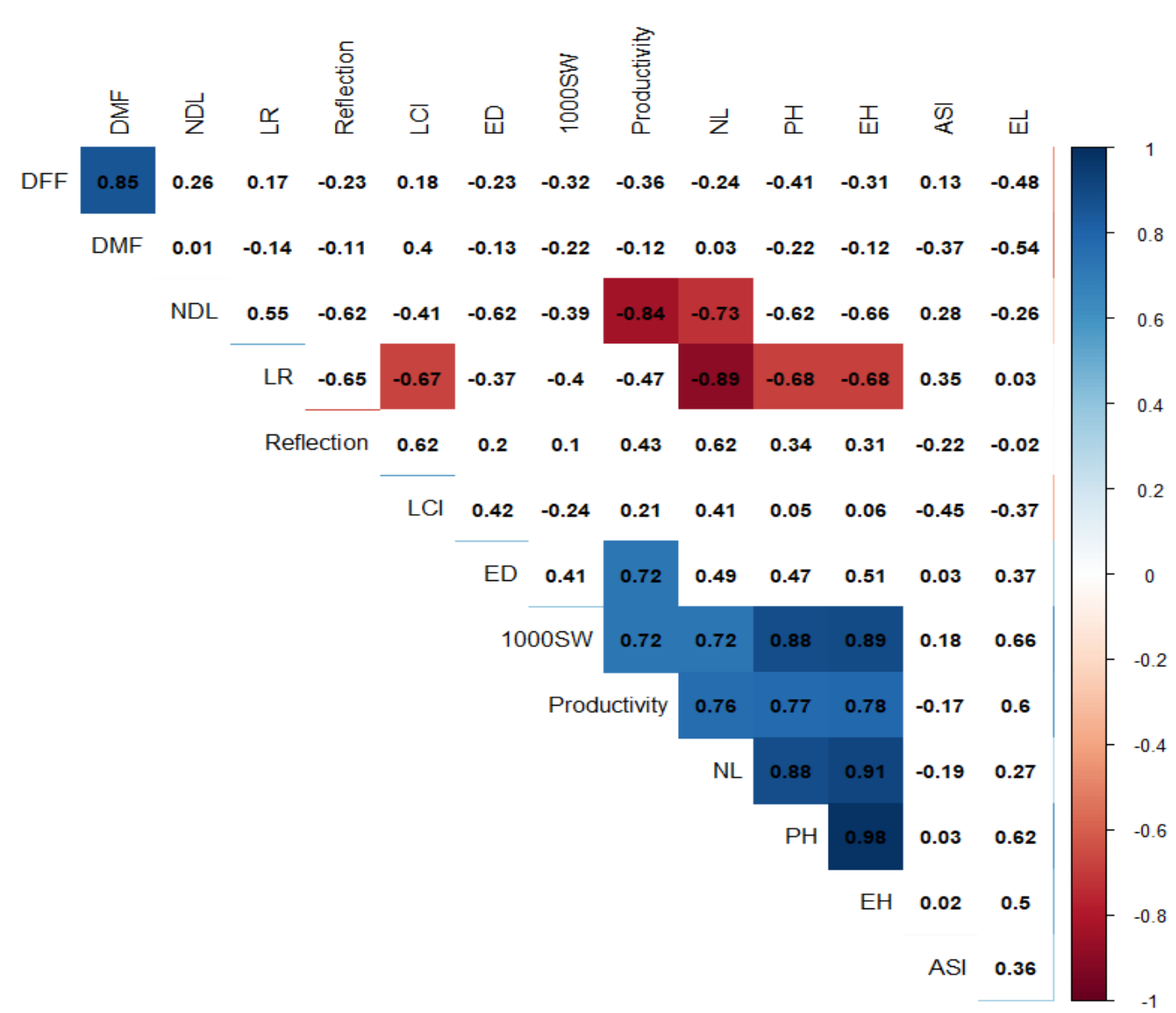

Figure 2. Heatmap based Pearson Correlation Analysis towards all STI Characters significant towards interaction (1000SW: 1000 seed weight, ASI: Anthesis silking interval, DFF: Days of female flowering, DMF: Days of male flowering, ED: Ear diameter, EH: Ear height, EL: Ear length, LCI: Leaf chlorophyll index, LR: Leaf rolling, NDL: Number of dried leaves, NL: Number of leaves, PH: Plant height)

According to Jolliffe (2002), positive and negative signs were limited to the variance direction of characters, making the eigenvector useful in positive conditions. However, due to their interpretation of tolerance, the number of leaves and leaf rolling were changed. Therefore, the selection index formed had the following formula:

Selection index $=0.358$ plant height $(\mathrm{PH})+0.362$ number of leaves (NL) - 0.315 number of dried leaves (NDL) + 0.352 ear height $(\mathrm{EH})+0.263$ ear diameter $(\mathrm{ED})-0.291$ leaf rolling $(\mathrm{LR})+0.189$ leaf chlorophyll index $(\mathrm{LCI})+$ 0.2931000 seed weight $(1000 \mathrm{SW})+0.346$ productivity.

Various research has reported PCA application in finding a variation of an object and other variables (Jolliffe 2002; Mattjik and Sumertajaya 2011; Singh et al. 2015; Anshori et al. 2018; Fadhli et al. 2020). This analysis was effective in preventing multicollinearity or overlapped variance (Jolliffe 2002; Mattjik and Sumertajaya 2011), can increase selection index objectivity in genotype, and is linked with the index from Smith Hazel (Godshalk and Timothy 1988). Based on the research, determination of weighing value from PC eigenvector can affect priority characters towards drought stress. Productivity relatively has a low heritability value under abiotic stress (Kassahun et al. 2013; Fellahi et al. 2018), hence, the utilization of the characters with linear and larger variance can increase selection effectiveness under drought stress. Furthermore, Alsabah et al. (2019) reported that the variety of productive tillers was larger than productivity, and this was in line with path analysis results. According to Akbar et al. (2019) and Anshori et al. (2019), eigenvector application can be combined with path analysis. However, due to the small number of genotypes in the research, the analysis was considered unnecessary. Path analysis with fewer samples can cause multicollinearity (Olivoto et al. 2017; Sari et al. 2018), hence, this index application could increase the selection effectiveness of synthetic maize under drought stress. Based on the selection index, productivity does not dominate index variance but is the main character, as a result, the index requires adjustment. This has been reported by Anshori et al. (2019) on rice under salinity stress and Farid et al. (2021) on wheat under drought stress. Therefore, the adjusted selection index was formulated in this study. 
Table 2. Principal component analysis based on STI Characters significant towards interaction

\begin{tabular}{lcccccccccc}
\hline \multicolumn{1}{c}{ Variables } & PC1 & PC2 & PC3 & PC4 & PC5 & PC6 & PC7 & PC8 & PC9 \\
\hline PH & -0.358 & 0.125 & -0.134 & 0.219 & -0.008 & 0.075 & 0.004 & 0.342 & -0.191 \\
NL & -0.362 & -0.130 & -0.099 & 0.218 & -0.097 & -0.029 & -0.024 & -0.132 & -0.173 \\
NDL & 0.315 & 0.126 & -0.103 & 0.277 & -0.135 & 0.427 & 0.436 & -0.409 & -0.123 \\
DFF & 0.176 & -0.302 & -0.543 & -0.154 & -0.162 & -0.256 & 0.089 & -0.100 & -0.497 \\
DMF & 0.053 & -0.429 & -0.507 & -0.019 & 0.162 & -0.109 & 0.189 & 0.179 & 0.361 \\
ASI & 0.050 & 0.349 & -0.254 & -0.169 & -0.772 & -0.072 & -0.118 & 0.130 & 0.237 \\
EH & -0.352 & 0.087 & -0.246 & 0.182 & -0.011 & 0.076 & -0.275 & 0.168 & 0.039 \\
ED & -0.263 & -0.016 & -0.006 & -0.662 & -0.057 & 0.392 & -0.130 & -0.195 & -0.307 \\
Reflection & -0.219 & -0.220 & 0.387 & 0.113 & -0.391 & -0.529 & 0.180 & -0.263 & -0.050 \\
LR & 0.291 & 0.281 & -0.047 & -0.322 & 0.175 & -0.312 & -0.123 & -0.131 & 0.245 \\
LCI & -0.189 & -0.429 & 0.137 & -0.222 & -0.220 & 0.332 & 0.267 & 0.047 & 0.462 \\
EL & -0.198 & 0.422 & -0.044 & -0.162 & 0.086 & -0.114 & 0.725 & 0.288 & -0.071 \\
1000SW & -0.293 & 0.235 & -0.331 & 0.188 & 0.075 & 0.031 & -0.040 & -0.580 & 0.327 \\
Productivity & -0.346 & 0.045 & -0.040 & -0.277 & 0.275 & -0.262 & 0.110 & -0.257 & 0.046 \\
PV & 0.478 & 0.219 & 0.104 & 0.071 & 0.057 & 0.041 & 0.019 & 0.012 & 0.000 \\
CV & 0.478 & 0.697 & 0.801 & 0.872 & 0.929 & 0.970 & 0.988 & 1.000 & 1.000 \\
EigenValues & 6.690 & 3.072 & 1.449 & 0.994 & 0.802 & 0.571 & 0.258 & 0.165 & 0.000 \\
\hline
\end{tabular}

Notes: PV: proportion of variance, CV: cumulative of variance, 1000SW: 1000 seed weight, ASI: Anthesis silking interval, DFF: Days of female flowering, DMF: Days of male flowering, ED: Ear diameter, EH: Ear height, EL: Ear length, LCI: Leaf chlorophyll index, LR: Leaf rolling, NDL: Number of dried leaves, NL: Number of leaves, PH: Plant height

Table 3. STI Selection index on 9 synthetic maize genotypes

\begin{tabular}{lcccccccccc}
\hline \multicolumn{1}{c}{ Genotype } & PH & NL & NDL & EH & ED & LR & LCI & 1000SW & Pr & Selection index \\
\hline Syn_2-1 & 0.70 & 0.78 & 2.09 & 0.69 & 0.89 & 1.73 & 0.99 & 0.69 & 0.55 & 0.23 \\
Syn_2-2 & 0.99 & 1.00 & 1.42 & 0.97 & 0.85 & 1.45 & 1.00 & 0.93 & 0.67 & 0.79 \\
Syn_2-4 & 0.80 & 0.87 & 2.86 & 0.82 & 0.78 & 1.64 & 0.98 & 0.95 & 0.50 & 0.16 \\
Syn_2-8 & 0.82 & 0.91 & 2.03 & 0.86 & 0.88 & 1.52 & 1.00 & 0.82 & 0.48 & 0.43 \\
Syn_2-15 & 1.00 & 1.02 & 1.63 & 1.00 & 1.03 & 1.45 & 1.01 & 1.06 & 0.75 & 0.85 \\
Syn_2-16 & 1.01 & 1.01 & 1.28 & 1.01 & 0.99 & 1.48 & 1.00 & 1.09 & 0.86 & 0.97 \\
Bisma & 0.90 & 0.86 & 2.78 & 0.86 & 0.83 & 1.59 & 0.98 & 0.92 & 0.48 & 0.23 \\
Lamuru & 0.96 & 0.89 & 1.87 & 0.98 & 0.92 & 1.70 & 0.97 & 1.08 & 0.68 & 0.61 \\
Sukmaraga & 0.84 & 0.86 & 2.46 & 0.85 & 0.94 & 1.58 & 1.00 & 0.85 & 0.53 & 0.32 \\
\hline
\end{tabular}

Note: 1000SW: 1000 seed weight, ED: Ear diameter, EH: Ear height, LCI: Leaf chlorophyll index, LR: Leaf rolling, NDL: Number of dried leaves, NL: Number of leaves, PH: Plant height, Pr: Productivity

The adjusted concept is important because this analysis could avoid the overestimate interpretation (Anshori et al. 2019). The adjusted selection index can be conducted with some analysis. One of these adjusted analyses that could be conducted is correlation analysis. This analysis has been reported by Sabouri et al. (2008) and Chaudhary et al. (2017) on rice. Based on this, the combination of PCA weighting and correlation was performed in creating the selection index. The adjusted selection index was as follows:

Adjusted selection index $=(0.358 \times 0.77) \mathrm{PH}+(0.362 \mathrm{x}$ $0.76) \mathrm{NL}-(0.315 \times 0.85) \mathrm{NDL}+(0.352 \times 0.78) \mathrm{EH}+$ $(0.263 \times 0.72) \mathrm{ED}-0.291 \mathrm{LR}+0.189 \mathrm{LCI}+(0.293 \times 0.72)$ $1000 \mathrm{SW}+0.346$ productivity.

Adjusted selection index $=0.276 \mathrm{PH}+0.275 \mathrm{NL}-0.265$ $\mathrm{NDL}+0.275 \mathrm{EH}+0.189 \mathrm{ED}-0.291 \mathrm{LR}+0.189 \mathrm{LCI}+$ $0.2111000 \mathrm{SW}+0.346$ productivity.
The selection index result revealed 3 synthetic maize genotypes with a better index compared to Lamuru as check variety. These varieties were Syn_2-2 (0.79), Syn_215 (0.85), and Syn_2-16 (0.97). Lamuru is a composite variety with 7.6 tons ha $^{-1}$ productivity and is tolerant to drought, making it frequently planted in areas with long dry months (Mustikawati and Yulia 2011; Aqil et al. 2012; Prasetyo and Amin 2019). According to Suwarno et al. (2009), the use of control/check varieties is the common method for best-selected lines and has been used in detecting the best rice line resistant to blast disease. Therefore, the 3 synthetic maize lines were recommended as advance line candidates under drought stress based on the research.

In conclusion, plant height, number of leaves, number of dried leaves, ear height, ear diameter, leaf rolling, chlorophyll, and 1000 seed weight were characters that affected synthetic maize productivity variance in drought stress conditions. Meanwhile, the principal component analysis resulted in Adjusted Selection Index $=0.276$ plant 
height $(\mathrm{PH})+0.275$ number of leaves (NL) - 0.265 number of dried leaves (NDL) +0.275 ear height $(\mathrm{EH})+0.189$ ear diameter (ED) - 0.291 leaf rolling (LR) + 0.189 leaf chlorophyll index (LCI) +0.2111000 seed weight $(1000 \mathrm{SW})+0.346$ productivity. Through index selection, Syn_2-2, Syn_2-15 and Syn_2-16 were considered as drought stress adaptive lines. Therefore, these 3 lines can be recommended for further process as candidates of drought-tolerant varieties.

\section{REFERENCES}

Agriculture Ministry. 2018. Kementan Pastikan Produksi Jagung Nasional Surplus. www.pertanian.go.id/home/?show=news\&act=view\&id=3395 [Indonesian]

Akbar MR, Purwoko BS, Dewi IS, Suwarno WB, Sugiyanta. 2019 Selection of doubled haploid lines of rainfed lowland rice in preliminary yield trial. Biodiversitas 20 (10): 2796-2801. DOI: 10.13057/biodiv/d201003.

Al-Naggar AMM, Sabry SRS, Atta MMM, El-Aleem OMA. 2015. Effects of salinity on performance, heritability, selection gain and correlations in wheat (Triticum aestivum L.) doubled haploids. Sci Agric 10: 7083. DOI: 10.15192/PSCP.SA.2015.10.2.7083

Ali F, Ahsan M, Ali Q, Kanwal N. 2017. Phenotypic stability of Zea mays grain yield and its attributing traits under drought stress. Front Plant Sci 8:1 397. DOI: 10.3389/fpls.2017.01397

Alsabah R, Purwoko BS, Dewi IS, Wahyu Y. 2019. Selection index for selecting promising doubled haploid lines of black rice. SABRAO J Breed Genet 51 (4): 430-441.

Amzeri A, Daryono Bs, Syafii M. 2020. Genotype by environment and stability analyses of dryland maize hybrids. SABRAO J Breed Genet 52 (4): 355-368.

Anshori MF, Purwoko BS, Dewi IS, Ardie SW, Suwarno WB. 2018. Determination of selection criteria for screening of rice genotypes for salinity tolerance. SABRAO J Breed Genet 50 (3): 279-294.

Anshori MF, Purwoko BS, Dewi IS, Ardie SW, Suwarno WB. 2019. Selection index based on multivariate analysis for selecting doubledhaploid rice lines in lowland saline prone area. SABRAO J Breed Genet 51(2): 161-174.

Anshori MF, Purwoko BS, Dewi IS, Suwarno WB, Ardie SW. 2020 Cluster heatmap for detection of good tolerance trait on doubledhaploid rice lines under hydroponic salinity screening. IOP Conf Ser Earth Environ Sci 484 (1): 12001. DOI: 10.1088/17551315/484/1/012001.

Anshori MF, Purwoko BS, Dewi IS, Ardie SW, Suwarno WB. 2021. A new approach to select doubled haploid rice lines under salinity stress using indirect selection index. Rice Sci 28 (4): 368-378. DOI: 10.1016/j.rsci.2021.05.007.

Aqil M, Constance R, Zubachtirodin. 2012. Deskripsi Varietas Unggul Jagung. Badan Litbang Pertanian, Jakarta. [Indonesian]

Badr A, El-Shazly HH, Tarawneh RA, Börner A. 2020. Screening for drought tolerance in maize (Zea mays L.) germplasm using germination and seedling traits under simulated drought conditions. Plants 9 (5): 565. DOI: 10.3390/plants9050565.

Bänziger M, Pixley KV, Vivek B, Zambezi BT. 2000. Characterization of Elite Maize Germplasm Grown in Eastern And Southern Africa: Results of The 1999 Regional Trials Conducted by CIMMYT and the Maize and Wheat Improvement Research Network for SADC (MWIRNET). CIMMYT, Harare.

Baret F, Madec S, Irfan K, Lopez J, Comar A, Hemmerlé M, Dutartre D, Praud S, Tixier MH. 2018. Leaf-rolling in maize crops: from leaf scoring to canopy-level measurements for phenotyping. J Exp Bot 69 (10): 2705-2716. DOI: 10.1093/jxb/ery071.

Barik SR,Pandit E, Kumar Pradhan SK, Mohanty SP, Mohapatra T. 2019. Genetic mapping of morpho-physiological traits involved during reproductive stage drought tolerance in rice. Plos One 14 (12): e0214979. DOI: 10.1371/journal.pone.0214979.

Branković G, Dodig D, Pajić V, Kandić V, Knežević D, Đurić N, Živanović T. 2018. Genetic parameters of bread wheat and durum wheat genotypes for technological quality properties in Serbia. Zemdirbyste 105 (1): 39-48. DOI: 10.13080/z-a.2018.105.006
Bukhsh MAAHA, Ahmad R, Iqbal J, Maqbool MM, Ali A, Ishaque M, Hussain S. 2012. Nutritional and physiological significance of potassium application in maize hybrid crop production. Pak J Nutr 11: 187-202. DOI: 10.3923/pjn.2012.187.202

Chaudhary AP, Parmar DJ, Muniya SD, Darji VB. 2017. Construction of selection index using simple correlation coefficients and path coefficients (direct effects) as a weight in rice (Oryza sativa L.). Int J Curr Res 9 (7): 53864-53869.

Cooper M, Gho C, Leafgren R, Tang T, Messina C. 2014. Breeding drought-tolerant maize hybrids for the US corn-belt: Discovery to product. J Exp Bot 65: 6191-6204. DOI: 10.1093/jxb/eru064

Freshley D, Delgado-Serrano MM. 2020. Learning from the past in the transition to open-pollinated varieties. Sustainability 12: 4716. DOI: $10.3390 /$ su 12114716

Fromme DD, Spivey TA, Grichar WJ. 2019. Agronomic response of maize (Zea mays 1.) hybrids to plant populations. Int J Agron 2019: 3589768. DOI: 10.1155/2019/3589768.

Efendi R, Priyanto SB, Aqil M, Azrai M. 2019. Drought adaptation level of maize genotypes based on leaf rolling, temperature, relative moisture content, and grain yield parameters. IOP Conf Ser Earth Environ Sci 270: 012016. DOI: 10.1088/1755-1315/270/1/012016 [Indonesian]

Fadhli N, Farid M, Rafiuddin, Effendi R, Azrai M, Anshori MF. 2020. Multivariate analysis to determine secondary trait in selecting adaptive hybrid maize lines under drought stress. Biodiversitas 21 (8): 3617-3624. 10.13057/biodiv/d210826

Fahad S, Bajwa AA, Nazir U, Anjum SA, Farooq A, Zohaib A, Sadia S, Nasim W, Adkins S, Saud S, Ihsan MZ, Alharby H, Wu C, Wang D, Huang J. 2017. Crop production under drought and heat stress: Plant responses and management options. Front Plant Sci 8: 1147. DOI: $10.3389 /$ fpls.2017.01147

Farid M, Musa Y, Nasaruddin, Amin RM, Ridwan I. 2019. Tolerance of Wheat mutant (Triticum aestivum L.) genotypes in lowland against limited water availability. IOP Conf Ser Earth Environ Sci 235: 012028. DOI: 10.1088/1755-1315/235/1/012028.

Farid M, Nasaruddin, Musa Y, Ridwan I, Anshori MF. 2021. Effective screening of tropical wheat mutant lines under hydroponically induced drought stress using multivariate analysis approach. Asian J Plant Sci 20 (1): 172-182. DOI: 10.3923/ajps.2021.172.182.

Fellahi ZEA, Hannachi A, Bouzerzour H. 2018. Analysis of direct and indirect selection and indices in bread wheat (Triticum aestivum L.) segregating progeny. Intl J Agron 8312857: 1-11. DOI: $10.1155 / 2018 / 8312857$.

Fernandez GCJ. 1992. Effective selection criteria for assessing stress tolerance. In: Kuo CG (eds) Proceedings of the International Symposium on Adaptation of Vegetables and Other Food Crops in Temperature and Water Stress. 257: 270. Asian Vegetable Research and Development Center, Tainan, 13-18 August 1992. [Taiwan]

Galili T. 2015. Dendextend: An R package for visualizing, adjusting, and comparing trees of hierarchical clustering. Bioinformatics 31 (22): 3718-3720. DOI: 10.1093/bioinformatics/btv428.

Godshalk EB, Timothy DH. 1998. Factor and principal component analyses as alternatives to index selection. Theoret Appl Genet 76: 352-360. DOI: 10.1007/BF00265334.

Ghannoum O. 2009. C4 photosynthesis and water stress. Ann Bot 103 (4): 635-644. DOI: 10.1093/aob/mcn093

Hidayatullah A, Purwoko BS, Dewi IS, Suwarno WB. 2018. Agronomic performance and yield of doubled haploid rice lines in advanced yield trial. SABRAO J Breed Genet 50 (3): 242-253.

Islam MR, Kayess MO, Hasanuzzaman M, Rahman MW, Uddin MJ, Zaman MR. 2017. Selection index for genetic improvement of wheat (Triticum aestivum L.). J Chem Biol Physic Sci 7 (1): 1-8. DOI: 10.9734/IJPSS/2017/31046

Jolliffe IT. 2002. Principal Component Analysis, Second Ed. SpringerVerlag, New York.

Kandel BP. 2020. Status, prospect and problems of hybrid maize (Zea mays L.) in Nepal: A brief review. Genet Resour Crop Evol 68: 1-10. DOI: 10.1007/s10722-020-01032-0.

Kartina N, Purwoko BS, Dewi IS, Wirnas D, Sugiyanta. 2019. Genotype by environment interaction and yield stability analysis of doubled haploid lines of upland rice. SABRAO J Breed Genet 51 (2): 191204.

Kassahun BM, Alemaw G, Tesfaye B. 2013. Correlation studies and path coefficient analysis for seed yield and yield components in Ethiopian coriander accessions. Afr Crop Sci J 21 (1): 51-59. 
Kassambra A, Mundt F. 2020. Factoextra: Extract and visualize the results of multivariate data analyses. https://cran.rproject.org/web/packages/factoextra/index.html

Kose A, Onder O, Bilir O, Kosar F. 2018. Application of multivariate statistical analysis for breeding strategies of spring safflower (Carthamus tinctorius L.). Turk J Field Crops 23 (1): 12-19. DOI: $10.17557 /$ tjfc. 413818 .

Kumar R, Kaul J, Dubey RB, Singode A, Chikkappa GK, Manivannan A, Debnath MK. 2015. Assessment of drought tolerance in maize (Zea mays 1.) based on different indices. SABRAO J Breed Genet 47 (3) 291-298.

Kutka. 2011. Open-pollinated vs. Hybrid maize cultivars. Sustainability 3: 1531-1554. DOI: 10.3390/su3091531

Lin CS, Binns MR, Lefkovirch. 1986. Stability analysis: Where do we stand?. Crop Sci 26: 894-900. DOI 10.2135/cropsci1986.0011183X002600050012x.

Mattjik AA, Sumertajaya IM. 2011. Multivariate Analysis Using SAS. FMIPA IPB, Bogor. [Indonesian]

Mendiburu FD. 2020. Agricolae: Statistical Procedures for Agricultural Research. https://CRAN.R-project.org/package=agricolae .

Monneveux P, Sanchez C, Beck D, Edmeades GO. 2005. Drought tolerance improvement in tropical maize source populations: Evidence of progress. Crop Sci 46 (1): 180-191. DOI: 10.2135/cropsci2005.04-0034.

Mohamadi SF, Bagheri N, Kiani G, Jelodar NB. 2017. Evaluation of different rice genotypes in response to salinity stress. Biol Forum Int J 9 (1): 174-182

Mustikawati DR, Yulia P. 2011. Introduksi varietas unggul jagung komposit di Lampung. Pros Sem Nas Serealian 2011. Badan Litbang Pertanian, Jakarta. [Indonesian]

Obeng-Bio E, Bonsu M, Obeng-Antwi K, Akromah R. 2011. Greenhouse assessment of drought tolerance in maize (Zea mays L.) using some plant parameters. Afr J Plant Sci 5 (14): 823-828. DOI: 10.5897/AJPS11.113.

Olivoto T, de Souza VQ, Nardino M, Carvalho IR, Ferrari M et al. 2017. Multicollinearity in path analysis: A simple method to reduce its effects. Agron J 109 (1): 131-142. DOI: 10.2134/agronj2016.04.0196.

Peternelli LA, Moreira EFA, Nascimento M, Cruz CD. 2017. Artificial neural networks and linear discriminant analysis in early selection among sugarcane families. Crop Breed Appl Biotechnol 17 (4): 299 305. DOI: 10.1590/1984-70332017v17n4a46.

Prasetyo WB, Amin M. 2019. Kajian pengembangan jagung lamuru di Kutai Kartanegara untuk mendukung peningkatan produksi di Kalimantan Timur. Pros Sem Nas Masy Biodiv Indon 5: 303-306. DOI: $10.13057 / \mathrm{psnmbi} / \mathrm{m050228}$. [Indonesian]

Raza MA, Saeed A, Munir H, Munawar A, Kamran A, Rehman F, Riaz A 2018. Improving salt tolerance and weight percent reduction in tomato by exploiting physio-agronomic seedling traits. Afr J Agric Res 13 (13): 607-616. DOI: 10.5897/AJAR2017.12920.

Rajamani S, Sreekanth M, Naik VS, Ratnam M. 2016. Selection indices for yield attributing characters improvement in pigeon pea (Cajanus cajan L. Millspaugh). Int J Life Sci Scienti Res 2 (2): 127-129.
Saad FF, El-Mohsen AAA, El-Shafi MAA, Al-Soudan IH. 2014. Effective selection criteria for evaluating some barley crosses for water stress tolerance. Egypt J Plant Breed 17 (6): 79-98. DOI: 10.12816/0011664

Sabagh AE, Barutçular C, Islam MS. 2017. Relationships between stomatal conductance and yield under defcit irrigation in maize (Zea mays L.). J Exp Biol Agric Sci 5 (1): 14-21. DOI: 10.18006/2017.5(1).014.021.

Sabouri H, Rabiei B, Fazlalipour M. 2008. Use of selection indices based on multivariate analysis for improving grain yield in rice. Rice Sci 15 : 303-310. DOI: 10.1016/S1672-6308(09)60008-1.

Sah RP, Chakraborty M, Prasad K, Pandit M, Tudu VK, Chakravarty MK, Narayan SC, Rana M, Moharana D. 2020. Impact of water deficit stress in maize: Phenology and yield components. Sci Rep 10: 2944. DOI: 10.1038/s41598-020-59689-7.

Sari, Lúcio AD, Olivoto T, Krysczun DK, Tischler AL, Drebes L. 2018. Scientific Notes Interference of sample size on multicollinearity diagnosis in path analysis. Pesq Agropec Bras 53 (6): 769-773. DOI: 10.1590/S0100-204X2018000600014.

Sharma R, Adhikari P, Shrestha J, Acharya BP. 2019. Response of maize (Zea mays L.) hybrids to different levels of nitrogen. Archives Agric Environ Sci 4 (3): 295-299. DOI: 10.26832/24566632.2019.040306

Sitaresmi T, Suwarno WB, Gunarsih C, Nafisah, Nugraha Y, Sasmita P, Daradjat AA. 2019. Comprehensive stability analysis of rice genotypes through multi-location yield trials using PBSTAT-GE. SABRAO J Breed Genet 51 (4): 355-372.

Silva Ard, Nascimento M, Cecon PR, Sapucay MJLC, Rêgo ERD, Barbosa LA. 2013. Path analysis in multicollinearity for fruit traits of pepper. Idesia 31: 55-60. DOI: 10.4067/S071834292013000200008

Singh S, Sengar RS, Kulshreshtha N, Datta D, Tomar RS, Rao VP, Garg D, Ojha A. 2015. Assessment of multiple tolerance indices for salinity stress in bread wheat (Triticum aestivum L.). J Agric Sci 7 (3): 49-57. DOI: $10.5539 /$ jas.v7n3p49.

Song L, Jin J, He J. 2019. Effects of severe water stress on maize growth processes in the field. Sustainability 11: 5086. DOI: $10.3390 / \mathrm{su} 11185086$

Souza TC, Magalha PC, Castro EM, Albuquerque PEP, Marabesi AM. 2013. The influence of ABA on water relation, photosynthesis parameters, and chlorophyll fluorescence under drought conditions in two maize hybrids with contrasting drought resistance. Acta Physiol Plant 35: 515-527. DOI: 10.1007/s11738-012-1093-9.

Suwarno, Lubis E, Hairmansis A, Santoso. 2009. Development of a package of 20 varieties for blast management on upland rice. In: Wang G L, Valent B (eds) Advances in Genetics, Genomics and Control Rice Blast Disease. Springer, Dordrecht, Netherlands.

Wei T, Simko V. 2017. R Package "corrplot": Visualization of A Correlation Matrix (Version 0.84). https://github.com/taiyun/corrplot

Witt, Galiciab L, Liseca J, Cairnsc J, Tiessend A, Arause JL, PalaciosRojasb N, Ferniea AR. 2012. Metabolic and phenotypic responses of greenhouse-grown maize hybrids to experimentally controlled drought stress. Mol Plant 5 (2): 401-417. DOI: $10.1093 / \mathrm{mp} / \mathrm{ssr} 10.2$

Yue H, Chen S, Bu J, Wei J, Peng H, Li Y, Li C, Xie J. 2018. Response of main maize varieties to water stress and comprehensive evaluation in hebei province. IOP Conf. Series: Earth Environ Sci 108: 042002. DOI: $10.1088 / 1755-1315 / 108 / 4 / 042002$ 